\title{
Naturally-Occurring Glucosinolates, Glucoraphanin and Glucoerucin, are Antagonists to Aryl Hydrocarbon Receptor as Their Chemopreventive Potency
}

\author{
Ahmad Faizal Abdull Razis ${ }^{1,2 *}$, Noramaliza Mohd Noor ${ }^{3}$
}

\begin{abstract}
As a cytosolic transcription factor, the aryl hydrocarbon (Ah) receptor is involved in several pathophysiological events leading to immunosuppression and cancer; hence antagonists of the Ah receptor may possess chemoprevention properties. It is known to modulate carcinogen-metabolising enzymes, for instance the CYP1 family of cytochromes P450 and quinone reductase, both important in the biotransformation of many chemical carcinogens via regulating phase I and phase II enzyme systems. Utilising chemically-activated luciferase expression (CALUX) assay it was revealed that intact glucosinolates, glucoraphanin and glucoerucin, isolated from Brassica oleracea L. var. acephala sabellica and Eruca sativa ripe seeds, respectively, are such antagonists. Both glucosinolates were poor ligands for the Ah receptor; however, they effectively antagonised activation of the receptor by the avid ligand benzo[a]pyrene. Indeed, intact glucosinolate glucoraphanin was a more potent antagonist to the receptor than glucoerucin. It can be concluded that both glucosinolates effectively act as antagonists for the $\mathrm{Ah}$ receptor, and this may contribute to their established chemoprevention potency.
\end{abstract}

Keywords: Glucoraphanin - glucoerucin - aryl hydrocarbon receptor - CALUX - chemoprevention

Asian Pac J Cancer Prev, 16 (14), 5801-5805

\section{Introduction}

The aryl hydrocarbon $(\mathrm{Ah})$ receptor is a cytosolic transcription factor participated progressively in many patho-physiological processes, for example immunosuppression and cancer, with the basic mechanisms being presently investigated. Furthermore, it modulates carcinogen-metabolising enzymes, for instance the CYP1 family of cytochromes P450 and Phase II detoxifying enzymes, including quinone reductase, aldehyde dehydrogenase, glucuronosyltransferase and glutathione S-transferase (Safe, 2001; Abdull Razis and Mohd Noor, 2013) which mainly take place in the biotransformation of major classes of chemical carcinogens (Ioannides and Lewis, 2004). Ligands to this receptor are believed to be harmful to the living organism, and consist of various important groups of chemical carcinogens involving polycyclic aromatic hydrocarbons such as benzo(a) pyrene (Pushparajah et al., 2008; Wohak et al., 2014). The Ah receptor is considered as an orphan receptor with no endogenous ligand being so far identified; the highly toxic, halogenated aromatic hydrocarbon, 2,3,7,8-tetrachlorodibenzo-p-dioxin (TCDD), is the absolute avid ligand of this receptor identified so far (Hanieh, 2014). In brief, a ligand interacts with the receptor followed by translocation into the nucleus, a location where it act together with another protein, the translocator known as aryl hydrocarbon receptor nuclear translocator (Arnt); the heterodimer interacts with its DNA response elements leading to elevated transcription of several gene products, a number of which are involved in tumourigenesis. In fact, null mice Ah receptor was resistant to the mutagenicity of the polycyclic aromatic hydrocarbon benzo[a]pyrene (Shimizu et al., 2000). In addition, experimental studies demonstrated that Arnt is needed for the initiation of the tumour by the same carcinogen (Shi et al., 2009).

Cassia seed and rosemary that were noted to have health benefit effects were also demonstrated to contain natural Ah receptor agonists (Amakura et al., 2014). Gene expression analyses up-regulated by these agonists showed most of the genes engaged in dioxin-related toxic effects were modulated in the same way. In contrast, antagonists of the Ah receptor-mediated function, for example 3'-methoxy-4'-nitroflavone and 6,2',4'-trimethoxyflavone (TMF), are potentially beneficial and may have therapeutic

${ }^{1}$ Food Safety Research Centre (FOSREC), Faculty of Food Science and Technology, ${ }^{2}$ Laboratory of UPM-MAKNA Cancer Research, Institute of Bioscience, ${ }^{3}$ Department of Imaging, Faculty of Medicine and Health Sciences, Universiti Putra Malaysia, Selangor, Malaysia*For correspondence: madfaizal@upm.edu.my 
properties (Lu et al., 1995; Murray et al., 2010). It has been shown that in Mcf7 cells, 3'-methoxy-4'-nitroflavone impaired the induction of ethoxyresorufin O-deethylase by TCDD; furthermore, co-treatment of Mcf7 cells with such flavones in the presence of TCDD or [3H]TCDD resulted in dose-dependent suppression of TCDD-induced CYP1A1 mRNA levels and formation of radiolabeled nuclear Ah receptor complex (Lu et al., 1995). Similarly, 6,2 ',4'-trimethoxyflavone, newly identified as an Ah receptor ligand, was capable of competing with agonists, for example benzo[a]pyrene and TCDD, efficiently deterring AhR-induced transactivation of endogenous targets and a heterologous reporter, such as CYP1A1, independent of cell lineage or species (Murray et al., 2010). Thus, clearly chemicals which function as antagonists of this receptor may function as chemopreventive agents.

The chemoprevention properties of cruciferous vegetables have been ascribed to glucosinolates, a group of sulphur with glycosides, which can be found at significant amounts in these vegetables (Abdull Razis and Mohd Noor, 2013). The putative opinion is that glucosinolates were not directly contributed to the chemoprevention effects, nonetheless their hydrolyzed-products for example the isothiocyanates. It has been presumed that intact glucosinolates, due to their water solubility, could not to reach the blood circulation after oral intake. Nevertheless, it was shown that, glucoraphanin, in any case in dogs and rats, able to absorb intact after oral intake (Bheemreddy and Jeffery, 2007; Cwik et al., 2010). Male F344 rats administered purified glucoraphanin at 150 $\mu \mathrm{mol} / \mathrm{kg}$ resulted in $5 \%$ of the oral dose remains intact in urine (Bheemreddy and Jeffery, 2007). Glucoraphanin in plasma was detectable in animals administered with glucoraphanin in comparison with control animals; in dog the levels were ranging from 2900 to $15,000 \mathrm{ng} /$ $\mathrm{mL}$ after receiving oral dose at $200 \mathrm{mg} / \mathrm{kg}$ /day of body weight for 3 days, while in rats the mean concentrations after 13 days dosing at $10,50,100$, and $500 \mathrm{mg} / \mathrm{kg} /$ day were 49.9, 198, 416 and $1630 \mathrm{ng} / \mathrm{mL}$, respectively (Cwik et al., 2010). Moreover, in the rat, glucoraphanin could be condensed to glucoerucin via the reduction of the alkylsulfinyl glucosinolate (Bheemreddy and Jeffery, 2007); glucoerucin differs from glucoraphanin (Figure 1) only by the presence of oxygen on the sulphur atom (Chun et al., 2013). These findings urged us to evaluate whether intact glucosinolates capable of activating the Ah receptor and/or prevent its activation by benzo[a]pyrene. Experimental evidence is presented in these studies that glucosinolates, glucoraphanin and glucoerucin, are antagonists of the Ah receptor and this attribute may be an important contributor to their chemopreventive activity.

\section{Materials and Methods}

DMSO, benzo[a]pyrene and 2,3,7,8-tetrachlorodibenzop-dioxin (TCDD) (Sigma Co. Ltd., Poole, Dorset, UK), luciferase assay reagent and cell culture lysis reagent (Promega, Wisconsin, USA), penicillin-streptomycinneomycin, foetal calf serum, minimum essential medium $\alpha$ (MEM- $\alpha$ ) (Invitrogen, Paisley, Scotland) were commercially available. The recombinant mouse hepatoma cell line H1L1.1c2, transfected by Dr. Michael Denison (University of California, USA), was kindly donated by Prof. Aldo Roda (University of Bologna, Italy).

\section{Glucosinolates isolation}

Glucoerucin and glucoraphanin were isolated from Eruca sativa ripe seeds and Brassica oleracea L. var. acephala sabellica, respectively, as previously described (Visentin et al., 1992). Both glucosinolates were extracted using an Ultraturrax homogeniser at average speed for $15 \mathrm{~min}$ followed by homogenate centrifugation at $17,700 \times g$ for $30 \mathrm{~min}$. Utilising one-step anion exchange chromatography, glucosinolates were isolated from the extract according to Visentin et al. (1992). The purity of glucosinolate was subsequently improved via gelfiltration conducted using a XK 26/100 column packed with Sephadex G10 chromatography media (Amersham Biosciences), coupled with FPLC System (Pharmacia). All fractions were assessed by HPLC for pure glucosinolates followed by freeze-drying (Wagner et al., 2010). Finally, glucosinolates were characterised employing NMR spectrometry and the purity was checked using HPLC analysis according to the ISO 9167-1 method (EEC Regulation, 1990).

\section{Validation of the Ah receptor procedure}

Chemically-activated luciferase gene expression (CALUX) assay, employing recombinant mouse hepatoma H1L1.1c2 cell line transfected with a luciferase reporter gene under the control of dioxin-response enhancers was first validated using TCDD, the highest affinity ligand known for the $\mathrm{Ah}$ receptor. In addition, benzo[a]pyrene $(\mathrm{B}[\mathrm{a}] \mathrm{P})$, a known potent $\mathrm{Ah}$ receptor activator, was also investigated.

\section{Activation of the Ah receptor}

Utilising chemically-activated luciferase expression (CALUX) assay, PAHs interactions with the Ah receptor were investigated. Transfected H1L1.1c2 cells were cultured at $7 \times 10^{4}$ cells $/ \mathrm{mL}$ ) in 24-well plates, in $\alpha$-MEM supplemented with $10 \%$ FBS and penicillinstreptomycin-neomycin; for $24 \mathrm{~h}$ up to $50-70 \%$ confluent. Cells were subsequently exposed to glucosinolates, glucoerucin and glucoraphanin $\left(10^{-11}-10^{-5} \mathrm{M}\right)$, for $24 \mathrm{~h}$ at $37^{\circ} \mathrm{C}$ and $5 \% \mathrm{CO}_{2}$, and then washed with PBS; 100 $\mathrm{mL}$ of lysis reagent was pipetted into each well followed by incubation at room temperature for $15 \mathrm{~min}$. Cell lysates were then centrifuged at $13000 \mathrm{xg}$ for $2 \mathrm{~min}$, and luciferase activity was determined employing Promegastabilised luciferase assay reagent. Using Packard Lumicount microplate luminometer (Packard Instrument), luminescence was read at $562 \mathrm{~nm}$. The fluoresced light was quantified as relative light units (RLU), corrected for gain and normalised for cell number. Luciferase activity was expressed as percentage of binding of the ligands to the Ah receptor, where TCDD $\left(10^{-9} \mathrm{M}\right)$ served as a positive control, achieving $100 \%$ binding.

Interaction studies between glucosinolates, glucoraphanin and glucoerucin with $B[a] P$ on Ah receptor activation

In studies where the objective was to examine the 
Naturally-occurring Glucosinolates, Glucoraphanin and Glucoerucin, are Aryl Hydrocarbon Receptor Antagonists

ability of glucosinolates, glucoraphanin and glucoerucin to influence the activation of Ah receptor by polycyclic aromatic hydrocarbons, cells were treated with benzo[a] pyrene $\left(10^{-11}-10^{-5} \mathrm{M}\right)$ in the presence of either glucoraphanin or glucoerucin $\left(10^{-9}, 10^{-6} \mathrm{M}\right)$, for 24 hours.

\section{Results}

Validation of the Ah receptor procedure

Maximum activation was noted at a concentration of $10^{-9} \mathrm{M}$ when the CALUX assay was authenticated

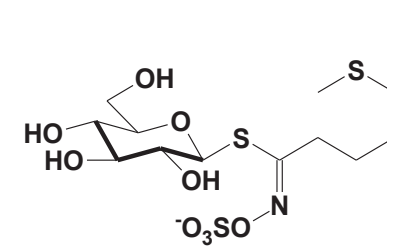

(a)

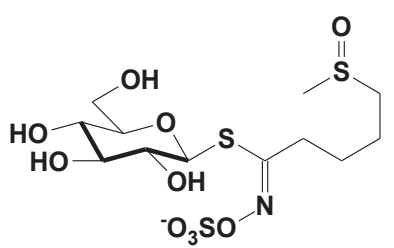

(b)
Figure 1. Structure of (A) Glucoerucin and (B) Glucoraphanin
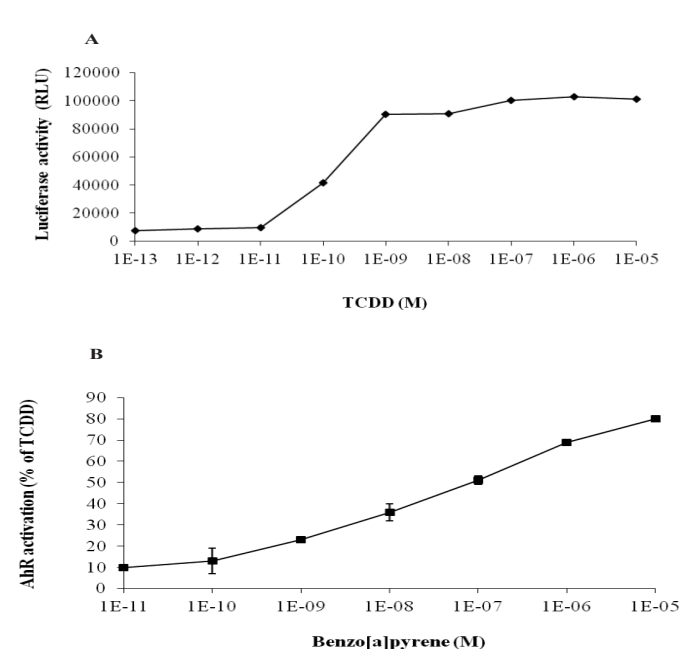

Figure 2. Active of the Ah Receptor by TCDD and Benzo [a] Pyrene. H1L1.1c2 Cells $\left(7 \times 10^{4}\right.$ cells $\left./ \mathrm{ml}\right)$ were incubated with TCDD $\left(10^{-13}-10^{-5} \mathrm{M}\right)$. (A) Benzo [a] Pyrene $\left(10^{-11}-10^{-5} \mathrm{M}\right)$;(B) for $24 \mathrm{~h}$. The activation ot the receptor is expressed as $\%$ of that achieved by TCDD $\left(10^{-9} \mathrm{M}\right)$. Results are expressed as mean $\pm \mathrm{SD}$ of triplicate determinations

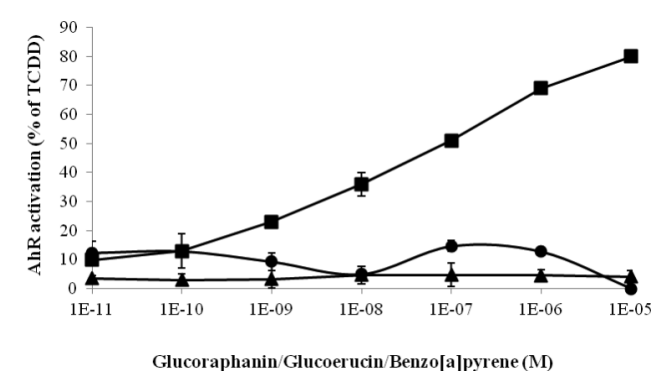

Figure 3. Active of the Ah Receptor by Benzo [a] Pyrene, glucoraphanin. H1L1.1c2 Cells $\left(7 \times 10^{4} \mathrm{cell} / \mathrm{ml}\right)$ were incubated in culture medium supplemented with benzo [a] pyrene or glucoraphanin or glucoerucin $\left(10^{-11}-10^{-5} \mathrm{M}\right)$ for $24 \mathrm{~h}$. Benzo(a)pyrene; $\boldsymbol{\Delta}$ glucoraphanin; $\boldsymbol{O}$ glucoerucin. Activation of the receptor is expressed as $\%$ of that achieved by TCDD $\left(10^{-9} \mathrm{M}\right)$. Results are expressed as mean $\pm \mathrm{SD}$ of triplicate determinations

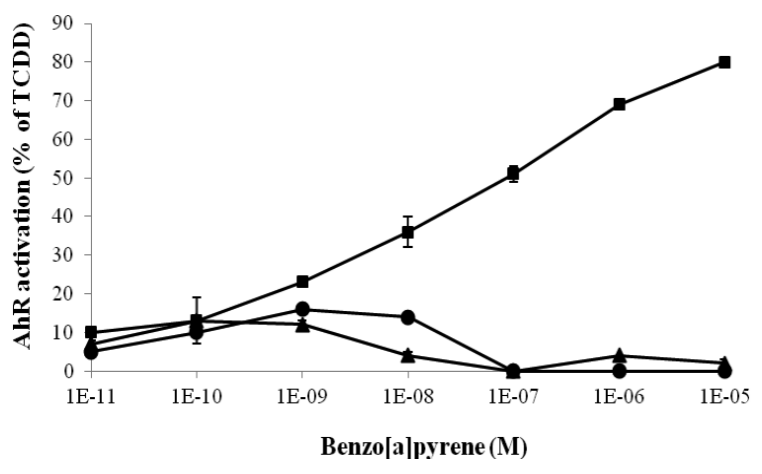

Figure 4. Modulation of the Benzo[a]pyrene Activation of the Ah Receptor by Glucoraphanin. H1L1.1c2 Cells $\left(7 \times 10^{4} \mathrm{cell} / \mathrm{ml}\right)$ were incubated in culture medium supplemented with benzo [a]pyrene $\left(10^{-11}-10^{-5} \mathrm{M}\right)$ alone or in combination with glucoraphanin $\left(10^{-6} \mathrm{M}\right.$ or $\left.10^{-9} \mathrm{M}\right)$ for $24 \mathrm{~h}$. Benzo [a]pyrene alone, Benzo[a]pyrene with glucoraphanin $\left(10^{-9} \mathrm{M}\right) ;$ Benzo[a]pyrene with glucoraphanin $\left(10^{-6} \mathrm{M}\right)$. The activation of the receptor is expressed as \% of that achieved by $\operatorname{TCDD}\left(10^{-9} \mathrm{M}\right)$. Results are expressed as mean $\pm \mathrm{SD}$ of triplicate determinations

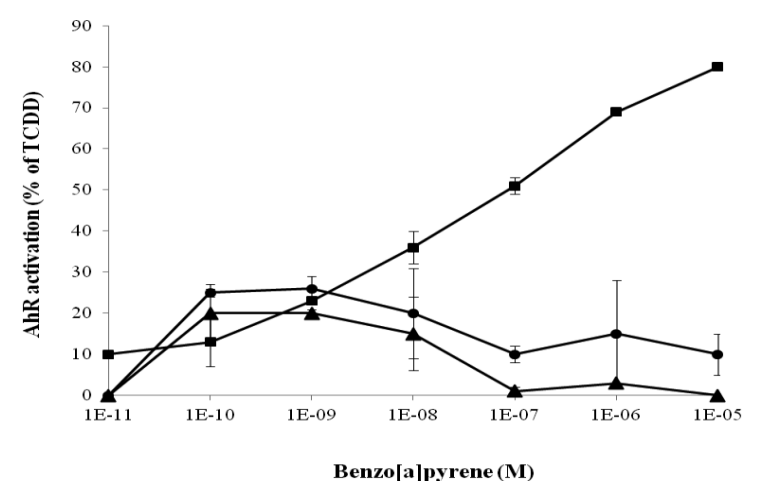

Figure 5. Modulation of the Benzo[a]pyrene Activation of the Ah Receptor by Glucoerucin. H1L1.1c2 Cells (7x10 cells $/ \mathrm{ml}$ ) were incubated in culture medium supplemented with benzo[a]pyrene $\left(10^{-11}-10^{-5} \mathrm{M}\right)$ alone or in combination with glucoerucin $\left(10^{-6} \mathrm{M}\right.$ or $\left.10^{-9} \mathrm{M}\right)$ for $24 \mathrm{~h}$. Benzo[a]pyrene alone, Benzo[a]pyrene with glucoerucin $\left(10^{-9} \mathrm{M}\right), \boldsymbol{\Delta}$ Benzo[a]pyrene with glucoerucin $\left(10^{-6} \mathrm{M}\right)$. The activation of the receptor is expressed as \% of that achieved by $\operatorname{TCDD}\left(10^{-9} \mathrm{M}\right)$. Results are expressed as mean $\pm \mathrm{SD}$ of triplicate determinations

with TCDD, the highest affinity ligand known for the aryl hydrocarbon (Ah) receptor (Figure 2A) as well as benzo[a]pyrene, with maximum activation occurring at a concentration of $10^{-5} \mathrm{M}$ (Figure $2 \mathrm{~B}$ ).

\section{Activation of the Ah receptor}

Glucosinolates were poor ligands in comparison with benzo[a]pyrene, but glucoerucin was found to be a relatively a better ligand than glucoraphanin, achieving $15 \%$ and $5 \%$ of activation of the receptor, respectively (Figure 3).

Interaction studies between glucosinolates glucoraphanin and glucoerucin with $B[a] P$ on Ah receptor activation

Studies were undertaken to evaluate whether the activation of the Ah receptor by benzo[a]pyrene was modulated in the presence of the glucosinolates glucoraphanin and glucoerucin, the precursors of sulforaphane and erucin respectively, to ascertain whether 
these glucosinolates displayed any antagonistic activity. Glucoraphanin at either concentrations of $10^{-6} \mathrm{M}$ or $10^{-9} \mathrm{M}$, effectively antagonised the benzo[a]pyrene activation to the Ah receptor, with the effect being more marked at the higher concentrations of benzo[a]pyrene $\left(10^{-7}-10^{-5} \mathrm{M}\right)$ (Figure 4).

Similarly, Figure 5 illustrates that benzo[a]pyrene activation of the Ah receptor appeared to be suppressed at the higher concentrations $\left(10^{-7}-10^{-5} \mathrm{M}\right)$ when $\mathrm{H} 1 \mathrm{~L} 1.1 \mathrm{c} 2$ cells exposed with benzo[a]pyrene $\left(10^{-11}-10^{-5} \mathrm{M}\right)$ in the presence of glucoerucin $\left(10^{-9} \mathrm{M}\right.$ or $\left.10^{-6} \mathrm{M}\right)$ for 24 hours. When comparing the antagonistic effects between glucoraphanin and glucoerucin at $10^{-9} \mathrm{M}$ on the activation of the Ah receptor by benzo[a]pyrene, glucoraphanin was found comparatively a better antagonist than glucoerucin (Figures 4 and 5).

\section{Discussion}

Many studies, utilising TCDD, have ascertained that ligand binding to the $\mathrm{Ah}$ receptor unleashes a plethora incidents that are harmful to the cell and organism (Hanieh, 2014). This receptor has been linked to different types of toxicity including developmental toxicity, tumourigenesis, immunotoxicity and inflammation. It is also clear that the $\mathrm{Ah}$ receptor plays an important role in human cancer through interaction with signaling pathways in a cell-specific manner, suggesting that this receptor may be a helpful device in the early detection and healing of cancer (Tsay et al., 2013). As a result, the role of antagonists to block ligand-mediated activation of the Ah receptor may be beneficial, particularly if these are widely-consumed phytochemicals with proven safety. The hydrolysed product of glucosinolates, isothiocyanates has been noted in epidemiology studies to lower cancer risk, and their anti-cancer properties have been approved in laboratory studies (Barouki et al., 2007). As electrophiles, they are likely to manipulate cellular processes via binding covalently to nucleic acids, proteins, or small molecules and may be indirectly reducing pools of cellular reductants (Hecht, 2000). A mechanistic study to determine the effect of isothiocyanates on CYP1A1 and CYP1A2 activity and expression, and Ah receptor translocation in Mcf7 cells demonstrated that both enzymes were significantly stimulated by benzo[a]pyrene, and isothiocyanates were able to inhibit the rise in activity (Nakamura et al., 2010). $A$ view has been expressed that the inhibition of CYP1A1 and CYP1A2 enzymes may serve as a useful strategy for cancer chemoprevention (Cho and Yoon, 2015). A likely causative mechanism of action of chemopreventive phytochemicals may be to avert the activation of Ah receptor by carcinogenic ligands such as benzo[a]pyrene.

In studies to assess whether the glucosinolate precursors of sulforaphane and erucin displayed any antagonistic effect on the activation of the Ah receptor by benzo[a]pyrene, both glucosinolates revealed a clear antagonistic effect, with glucoraphanin being relatively a better antagonist than glucoerucin. It has already been demonstrated that both glucosinolates induced the O-dealkylations of methoxy- and ethoxyresorufin (Abdull Razis and Mohd Noor, 2013), markers for CYP1 activity that is regulated by the Ah receptor through transcriptional activation (Okino et al., 2009). In other studies, glucosinolates such as sinigrin, glucoiberin, progoitrin and glucosinalbin were capable of inhibiting the level of $\beta$-naphthoflavone-induced CYP1A1 expression in Ah receptor-replete cells, and the inhibition effect was found to be dependent on the side chain of the glucosinolate (Whitlock, 1999). Meanwhile, a pronounced induction in CYP1A1 mRNA expression has been noted following exposure of HepG2 cells to another glucosinolate, glucoraphasatin (Wang et al., 1997), which could reflect activation of the Ah receptor by this glucosinolate.

In conclusion, the present studies demonstrate for the first time that glucosinolates, glucoraphanin and glucoerucin, are poor agonists but potent antagonists of the Ah receptor, properties that may attribute significantly to their established chemopreventive potency. As glucosinolates are widely consumed from cruciferous vegetables, are quickly absorbed following oral intake attaining good bioavailability, making them among the most potent dietary chemopreventive phytochemicals, and their function as antagonists of the Ah receptor attribute to their anti-carcinogenic activity.

\section{Acknowledgements}

The authors would like to thank Universiti Putra Malaysia for funding this work through GERAN UPM 2013 with project no. GP-IPM/2013/9400600.

\section{References}

Abdull Razis AF, Mohd Noor (2013). Cruciferous vegetables: dietary phytochemicals for cancer prevention. Asian Pac J Cancer Prev, 14, 1565-70.

Amakura Y, Yoshimura M, Takaoka M, et al (2014). Characterization of natural aryl hydrocarbon receptor agonists from cassia seed and rosemary. Molecules, 19, 4956-66.

Barouki R, Coumoul X, Fernandez-Salguero PM (2007) The aryl hydrocarbon receptor, more than a xenobiotic-interacting protein. FEBS Lett, 581, 3608-15.

Bheemreddy RM, Jeffery EH. (2007). The metabolic fate of purified glucoraphanin in F344 rats. J Agric Food Chem, 55, 2861-66.

Cho H-J, Yoon I-S. (2015). Pharmacokinetic interactions of herbs with cytochrome P450 and P-Glycoprotein. Evid Based Complementary Altern Med.

Chun J-H, Arasu MV, Lim Y-P, et al (2013). Variation of major glucosinolates in different varieties and lines of rocket salad. Hortic Environ Biotechnol, 54, 206-13.

Cwik MJ, Wu H, Muzzio M, et al (2010). Direct quantitation of glucoraphanin in dog and rat plasma by LC-MS/MS. $J$ Pharmaceut Biomed Analysis, 52, 544-9.

EEC Regulation 1864/90, 1990. Enclosure VIII. Off. J Eur Commun. 170, 27-34.

Hanieh H (2014). Toward understanding the role of aryl hydrocarbon receptor in the immune system: current progress and future trends. Biomed Res Int.

Hecht SS. (2000). Inhibition of carcinogenesis by isothiocyanates. Drug Met Rev, 32, 395-411.

Ioannides C, Lewis DF. (2004). Cytochrome P450 in the bioactivation of chemicals. Curr Top Med Chem, 4, 1767-88.

Lu YF, Santostefano M, Cunningham BD, et al (1995). 
Identification of 3'-methoxy-4'-nitroflavone as a pure aryl hydrocarbon $(\mathrm{Ah})$ receptor antagonist and evidence for more than one form of the nuclear Ah receptor in MCF-7 human breast cancer cells. Arch Biochem Biophys, 316, 470-7.

Murray IA, Flaveny CA, DiNatale BC, et al (2010). Antagonism of aryl hydrocarbon receptor signalling by 6,2'-4'-trimethoxyflavone. J Pharmacol Exptl Ther, 332, 135-44.

Nakamura Y, Miyoshi M (2010). Electrophiles in food; the current status of isothiocyanates and their chemical biology. Biosci Biotechnol Biosc, 74, 242-5.

Okino ST, Pookot D, Basak S. et al (2009). Toxic and Chemopreventive Ligands Preferentially Activate Distinct Aryl Hydrocarbon Receptor Pathways: Implications for Cancer Prevention. Cancer Prev Res, 2, 251-6.

Pushparajah DS, Umachandran M, Nazir T, et al (2008). Upregulation of CYP1A/B in rat lung and liver, and human precision-cut slices by a series of polycyclic aromatic hydrocarbons; association with the Ah locus and importance of molecular size. Toxicol In Vitro, 22, 128-45.

Safe S. (2001). Molecular biology of the Ah receptor and its role in carcinogenesis. Toxicol Lett, 120, 1-7.

Shi S, Yoon DY, Hodge-Bell KC, et al (2009). The aryl hydrocarbon receptor nuclear translocator (Arnt) is required for tumor initiation by benzo[a]pyrene. Carcinogenesis, $\mathbf{3 0}$, 1957-61.

Shimizu Y, Nakatsuru Y, Ichinose M, et al (2000). Benzo[a] pyrene carcinogenicity is lost in mice lacking the aryl hydrocarbon receptor. Proc Natl Acad Sci USA, 97, 779-82.

Tsay JJ, Tchou-Wong KM, Greenberg AK, et al (2013). Aryl hydrocarbon receptor and lung cancer. Anticancer Res, 33, 1247-56.

Visentin M, Tava A, Iori R, Palmieri S. (1992). Isolation and Identification of trans-4-(methylthio)-3-butenylglucosinolate from radish roots (Raphanus sativus L.). $J$ Agric Food Chem, 40, 1687-91.

Wagner AE, Ernst I, Iori R, et al (2010). Sulforaphane but not ascorbigen, indole-3-carbinole and ascorbic acid activates the transcription factor Nrf2 and induces phase- 2 and antioxidant enzymes in human keratinocytes in culture. Exp Dermatol, 19, 137-44.

Wang H, Griffiths S, Williamson G. (1997). Effect of glucosinolate breakdown products on $\beta$-naphthoflavoneinduced expression of human cytochrome P450 $1 \mathrm{Al}$ via the Ah receptor in Hep G2 cells. Cancer Lett, 114, 121-5.

Whitlock JP, Jr (1999). Induction of cytochrome P4501A1. Annu Rev Pharmacol Toxicol, 39, 103-25.

Wohak LE, Krais AM, Kucab JE, et al (2014). Carcinogenic polycyclic aromatic hydrocarbons induce CYP1A1 in human cells via a p53 dependent mechanism. Arch Toxicol. 